\title{
Long-term impacts of exotic grazer removal on native shrub recovery, Santa Cruz Island, California
}

\author{
STEPHANIE G. YeLENIK ${ }^{1, *}$ \\ ${ }^{1}$ U.S. Geological Survey, Pacific Island Ecosystems Research Center, Box 44, Hawaii Volcanoes National Park, HI 96718
}

\begin{abstract}
A combination of overgrazing and exotic species introduction has led to the degradation of habitats worldwide. It is often unclear whether removal of exotic ungulates will lead to the natural reestablishment of native plant communities without further management inputs. I describe here my return to sites on Santa Cruz Island, California, 12 years after initial sampling in order to gain a long-term view on native shrub reestablishment into exotic grasslands after exotic grazer removal. Santa Cruz Island was grazed by feral sheep and cattle for over a century; these exotic grazers were removed in the late 1980s and feral pigs were removed in 2005-2006. I resampled 5 sites on south-facing slopes in the Central Valley of the island to quantify native shrub cover, density, and size. Previous data suggested that one species, Eriogonum arborescens, would be able to naturally recruit in exotic grass-dominated areas. Native shrubs have shown a modest increase in cover over time, although more striking was a sharp increase in the amount of dead shrub cover and density. Recruitment events during high rainfall years probably led to the slight increase in Eriogonum cover between sampling periods. Recent drought periods, however, have probably increased mortality and otherwise slowed shrub reestablishment in these arid sites.
\end{abstract}

Resumen.-La combinación del sobrepastoreo con la introducción de especies exóticas ha resultado en la degradación de hábitats a nivel mundial. Sin embargo, con frecuencia no es claro si la eliminación de ungulados exóticos podría conducir al restablecimiento natural de las comunidades de plantas nativas sin la necesidad de mayores esfuerzos de gestión. En este estudio, regresamos a los sitios de la Isla Santa Cruz, en California, doce años después del muestreo inicial para obtener una visión a largo plazo, acerca del restablecimiento de arbustos nativos en pastizales exóticos, posterior a la eliminación de animales de pastoreo exóticos. La Isla Santa Cruz fue sitio de pastoreo de ovejas y ganado silvestre durante más de un siglo; estos herbívoros exóticos fueron retirados a fines de la década de 1980 y los cerdos salvajes fueron eliminados en 2005-2006. Re-muestreamos cinco sitios en laderas orientadas al sur en el Valle Central de la isla para cuantificar la cobertura, la densidad y el tamaño de los arbustos nativos. Datos anteriores sugirieron que una especie, Eriogonum arborescens, podría ser capaz de reestablecerse naturalmente en áreas dominadas por pastizales exóticos. Los arbustos nativos mostraron un modesto incremento en cuanto a su cobertura a lo largo del tiempo, aunque fue más notable el incremento en la cobertura y densidad de arbustos muertos. Los eventos de reclutamiento durante los años con elevadas precipitaciones, probablemente condujeron al ligero aumento en la cobertura de Eriogonum entre los períodos de muestreo. Sin embargo, es probable que los recientes períodos de sequía aumentaran la mortalidad y ralentizaran el restablecimiento de los arbustos en estos sitios áridos.

Exotic plant and ungulate species introductions have led to type shifts of various ecosystems ranging from tropical and subtropical forests to Mediterranean grasslands and shrublands (Scholes and Archer 1997, Folke et al. 2004, Yelenik and D’Antonio 2013). These areas, which often did not evolve with native herbivorous mammals (Bowen and Van Vuren 1997), were cleared of native vegetation either mechanically or via the grazers themselves, and then were seeded or planted with highly productive exotic grasses (D'Antonio and
Vitousek 1992). Exotic grasses can change ecosystem properties such as soil erosion and nutrient cycling, incur direct competition for resources, and set up priority effects wherein current residents preclude later-arriving species (Wilcox et al. 2012, Yelenik and D'Antonio 2013, Young et al. 2015). Thus it is possible that native species will not naturally return to ecosystems even after exotic grazers are removed (Stohlgren et al. 1999, Valone et al. 2002). Some ecosystems, however, have shown an increase in native plant cover after exotic

*Corresponding author: syelenik@usgs.gov

orcid.org/0000-0002-9011-0769 
grazer removal (Yelenik and Levine 2010). Understanding the constraints that allow or deter native plant recovery will help managers streamline efforts to restore ecosystems.

Various factors can affect the ability of native species to reenter these ecosystems, including seed availability, climate, and competition (Young et al. 2005). First and foremost, seeds of native species must be available in the seedbank or disperse into the landscape (Holmes and Cowling 1997, Stylinski and Allen 1999). Seed availability can depend on the intensity at which the land was grazed and/or the amount of time since initial disturbance (Guariguata and Ostertag 2001, Foster et al. 2003). Even in the case of seed arrival, competition from other species-in particular exotic grasses in grazed systems-may stall native germination or survival. For example, Eliason and Allen (1997) found that clearing exotic grasses in postdisturbance California grasslands led to an increase in the germination, growth, and survival of the native shrub Artemisia californica.

Global climate change adds to the complexity of these ecosystems. It is increasingly recognized that climate change and species interactions combine to create multiple predictors of plant community change (Suttle et al. 2007, Levine et al. 2010, Alexander et al. 2015). In more arid environments, it is important to consider how changes in precipitation will alter species interactions and succession (Seabloom et al. 2003, Holmgren et al. 2006). For example, Levine et al. (2008) demonstrated that species in a California grassland showed a wide range of responses to interannual variability in rainfall, ranging from 9- to 100-fold increases in plant abundance. Importantly, it is the relative response of the native and exotic plants to altered precipitation that will drive overall population patterns (Levine et al. 2010). Thus, when considering long-term change in plant dynamics after exotic grazer removal, it is important to consider how climate has played a role, which will in turn allow better predictions of plant community change under future climate scenarios.

Islands make for important biological laboratories in which to explore the effects of exotic grazer removal and plant community change in part because of the relative ease with which invasive animals, such as exotic ungulates, can be eradicated there (Donlan et al. 2002). Santa Cruz Island, California, part of the Northern Channel Islands, was overgrazed by feral sheep and cattle for over a century (McEachern et al. 2010); sheep removal began in 1981 and was largely completed by 1989 (Schuyler 1993) and cattle removal took place in the late 1980s. I returned to field sites on Santa Cruz Island to remeasure transects that were established in 2004 in the transition zones between native coastal sage scrub and exotic grass-dominated communities (Yelenik and Levine 2010). Since feral ungulate eradication, woody vegetation has shown an overall increase across the California Channel Islands (Beltran et al. 2014, Van Vuren 2015), although the mechanisms behind which species are recovering and why are not yet well understood (Yelenik and Levine 2010, 2011).

The 12 years between sample points and the variable rainfall over that time offer valuable insights into long-term plant community dynamics and how these may relate to climate change. Previous work (2002-2006) showed that seeds of both dominant native shrub species (Eriogonum arborescens and Artemisia californica) were arriving in the grassland areas but that only Eriogonum seedlings were establishing (Yelenik and Levine 2010). It was concluded that this was due to competition from dominant exotic grasses that precluded Artemisia recruitment (Yelenik and Levine 2010, 2011). Given the past data, it was therefore predicted that long-term data would show Eriogonum shrubs increasing in abundance and cover over time while Artemisia shrubs maintained past abundance and cover. My objective with this study was to resample transects that were established in 2004 to determine whether the predictions about the abundance and cover of shrubs were correct. I then relate the plant data to climate data over the past 12 years and to past work to suggest mechanisms for shrub recruitment or a lack thereof and to suggest future research directions.

\section{Methods}

\section{Sites}

All field sampling and experiments were completed in the Central Valley of Santa Cruz Island, California. The $249-\mathrm{km}^{2}$ island is located $30 \mathrm{~km}$ offshore from Southern California and is the largest of the Northern Channel Islands chain. Santa Cruz Island has 


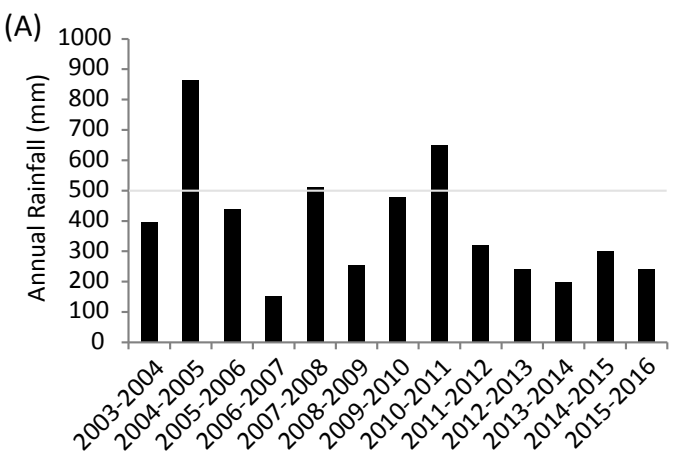

(B)

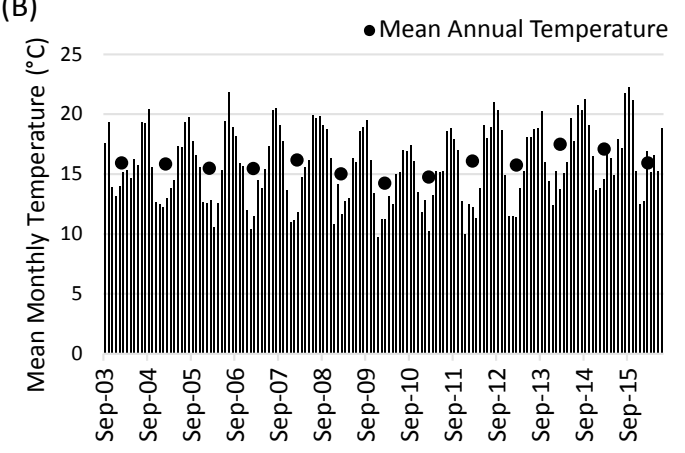

Fig. 1. (A) Annual rainfall summed over the growing season (September to September) on Santa Cruz Island, California. Average annual rainfall (quantified using data from 1904 to 1991; Junak et al. 1995) is noted with a gray line. (B) Mean monthly temperature (lines) and mean annual temperature (dots) over the study period.

a Mediterranean-type climate with cool, wet winters and hot, dry summers, leading to pulses of plant germination in winter with the first rains and senescence of annual plants during the summer drought. The island has 2 east-west ridgelines that help form a "Central Valley" that has a slightly warmer and drier climate than the coastal regions (Junak et al. 1995).

All sampling sites were on south-facing slopes in the Central Valley where native shrubs intergrade from rocky slopes into exotic annual grasslands at slightly lower elevations with more developed soils (Yelenik and Levine 2010). Rocky outcrops occur intermittently across all elevations; thus, this pattern occurs as a mosaic across the landscape (Appendixes 1, 2). In 2004 the dominant species on these south-facing slopes were the native shrubs Eriogonum arborescens Greene (Santa Cruz Island buckwheat) and Artemisia californica Less. (California sagebrush) and the exotic grass Avena barbata Pott ex Link (slender oat) (Yelenik and Levine 2010). Sites were located at least $1 \mathrm{~km}$ apart. Average rainfall (as compiled over 1904-1991, Junak et al. 1995) is $500 \mathrm{~mm}$ per year, although rainfall in California shows large between-year variation in both timing and annual totals.

Santa Cruz Island was a working ranch that was grazed by sheep since about 1850 and by domestic cattle since the late 1930s (Van Vuren and Coblentz 1987). The western 90\% of the island was purchased by The Nature Conservancy in 1978. Cattle and sheep were removed from The Nature Conservancy portion of the island by 1989 and feral pigs were subsequently removed in 2006 (Van Vuren and Coblentz 1987, Morrison 2007, Parkes et al. 2010).

\section{Precipitation Data}

Precipitation (Fig. 1A) and temperature (Fig. 1B) data were obtained from the Channel Islands National Park weather station (http: //www.wrcc.dri.edu/channel_isl/index.html [accessed September 2016]). I used data from the Diablo Peak station, which was the closest station to the study sites. Because of station malfunctions in parts of 2004 and 2005 for precipitation, I used 2006 data when both the Diablo Peak and Del Norte stations were functioning to relate the station values using linear regression $($ Diablo Peak $=1.01 *$ Del Norte $\left.0.07, r^{2}=0.99, P<0.001\right)$. I then estimated missing 2004 and 2005 Diablo Peak precipitation data using Del Norte data. Precipitation was summed annually using Septembers as endpoints in order to capture total rainfall over the winter growing season (Fig. 1A).

\section{Plant Community Sampling}

Transects were established in 6 sites in June 2004 in the transition zones between $100 \%$ shrubs and $100 \%$ grasses on south-facing slopes. A 30-m tape was extended parallel to the contour line of the slope in an area with $>90 \%$ (estimated observationally) cover by exotic annual grasses; random numbers were used to locate where the grass-to-shrub transect would fall. Transects were then run uphill (Appendix 1) perpendicular to the slope contour until they ended in areas with $>90 \%$ cover by native shrubs. Transects varied between $50 \mathrm{~m}$ and $95 \mathrm{~m}$ in length depending on the size of the transition zone. Both transect 

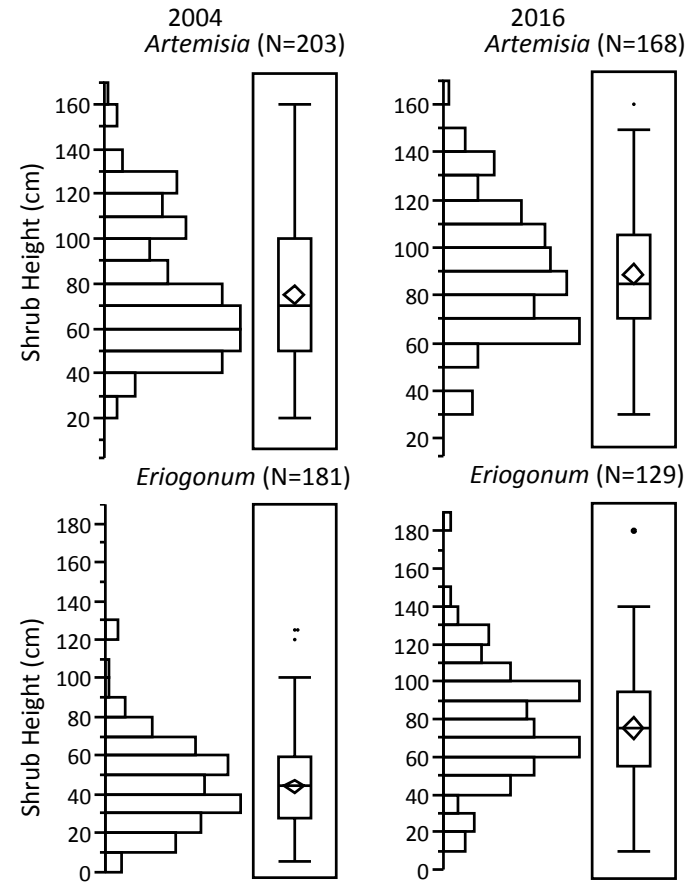

"transect sections" hereafter). The sampling design was such that upper transects were dominated by native shrubs, the lower transect was dominated by exotic annual grasses, and the middle section was mixed shrubgrassland. To determine whether the height of shrubs changed across sample years, I used separate one-way ANOVAs for each species, with year as a fixed effect and site as a random effect (see Fig. 2 for data structure). I normalized the number of shrubs for transect length, then asked whether the number of shrubs per meter had changed since last sampling using transect section as a fixed effect and site as a random effect in a one-way ANOVA. I analyzed the effects of year and transect section on the percent cover of Artemisia, Eriogonum, dead shrubs, and exotic grass using generalized linear models with a Poisson distribution to account for zero-inflated data. These generalized linear models had site, year, transect section, and year $\times$ transect section as fixed effects. All analyses were run with JMP 10.0.2 (SAS Institute, Cary, NC).

\section{RESUlts}

\section{Precipitation}

Only 3 of the 12 years between sample points had above average rainfall $(>500 \mathrm{~mm})$ during the growing season (Fig. 1A). One of these was the year directly after initial sampling (2004-2005) and the others were the 2007-2008 and the 2010-2011 growing seasons. The growing seasons for 2011-2016 received below-normal rainfall, ranging from $39 \%$ to $64 \%$ of the average rainfall. Annual temperature did not significantly vary between years during the study (Fig. 1B).

\section{Plant Community}

Over the past 12 years native shrubs have grown larger; the height of native shrubs (Fig. 2) increased for both species across sample dates (one-way ANOVA of height with year as a fixed effect and site as a random effect: Artemisia, $F=26.8, P<0.001$; Eriogonum, $F=102.9, P<0.001)$. In addition, the number of individual shrubs increased slightly in the lower grassland and the middle grassshrub transition sections of transects (Table 1). At the same time, numbers of individuals decreased in the uppermost, shrub-dominated sections of transects (Table 1), resulting in an 
TABle 1. Average change in number of Artemisia and Eriogonum shrubs in different sections of transects on Santa Cruz Island, California. Standard error (1 SE) is also shown.

\begin{tabular}{llcc}
\hline Species & $\begin{array}{c}\text { Transect } \\
\text { section }\end{array}$ & $\begin{array}{c}\text { Average } \\
\text { change (no.) }\end{array}$ & 1 SE \\
\hline Artemisia & lower & 1.40 & 0.51 \\
californica & middle & 3.60 & 1.40 \\
& upper & -6.80 & 9.22 \\
& total & -0.60 & 5.40 \\
Eriogonum & lower & 1.80 & 0.86 \\
arborescens & middle & 0.00 & 2.12 \\
& upper & -10.60 & 4.19 \\
& total & -2.93 & 3.60 \\
\hline
\end{tabular}

effect of transect section on change in numbers of shrubs between sample dates (one-way ANOVA of height, with transect section as a fixed effect and site as a random effect: $F=$ 4.6, $P=0.021)$.

By comparing the smallest meter mark at which shrubs were found between years (i.e., the lowest point on the hill in the grassland area on a transect), I was able to conclude that shrubs have reestablished farther along transects than in 2004. Eriogonum moved on average $15 \mathrm{~m}( \pm 6.5 \mathrm{~m})$ farther down transects into exotic-dominated grassland while Artemisia moved $11 \mathrm{~m}( \pm 6.2 \mathrm{~m})$.

In the 2004 census, only 2 shrubs $(0.6 \%)$ were noted as dead along all transects while 40 shrubs $(13 \%)$ were noted as dead in 2016. This could account for the decrease in shrub numbers along the upper portions of transects. Artemisia had 2, 6, and 16 dead shrub individuals in the lower, middle, and upper transect sections, respectively. Eriogonum had 1,6 , and 9 dead shrub individuals in the lower, middle, and upper transect sections, respectively. Because Artemisia shrubs were somewhat more numerous than Eriogonum overall, percentages of dead shrubs were similar for each species $(12.4 \%$ Eriogonum and 14.3\% Artemisia). Percent cover data (Table 2, Fig. 3) also showed an increase in the cover of dead shrubs between 2004 and 2016 along all portions of the transect (i.e., shrubs surrounded by grasses in the lower portions as well as shrubs surrounded by other shrubs in the upper portions). There was a greater increase in dead shrub cover in the upper sections of transects where shrub cover was higher overall (Table 2, Fig. 3).

Eriogonum showed a slight increase in shrub cover across transects, although most of

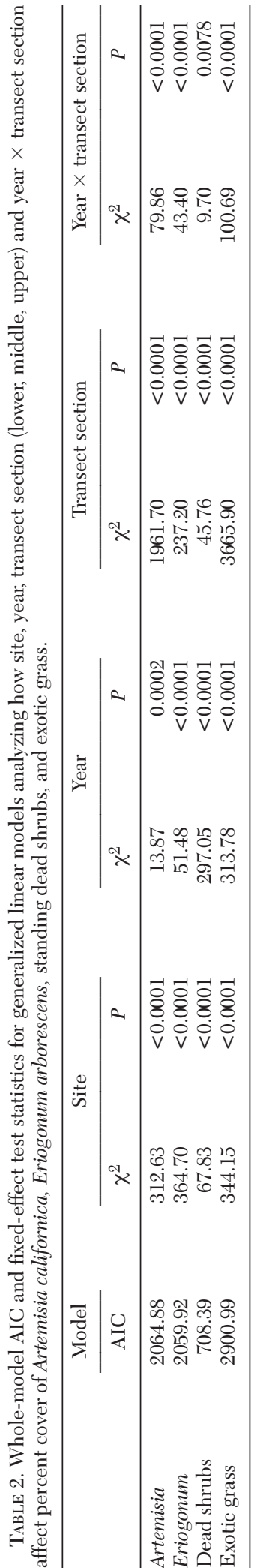



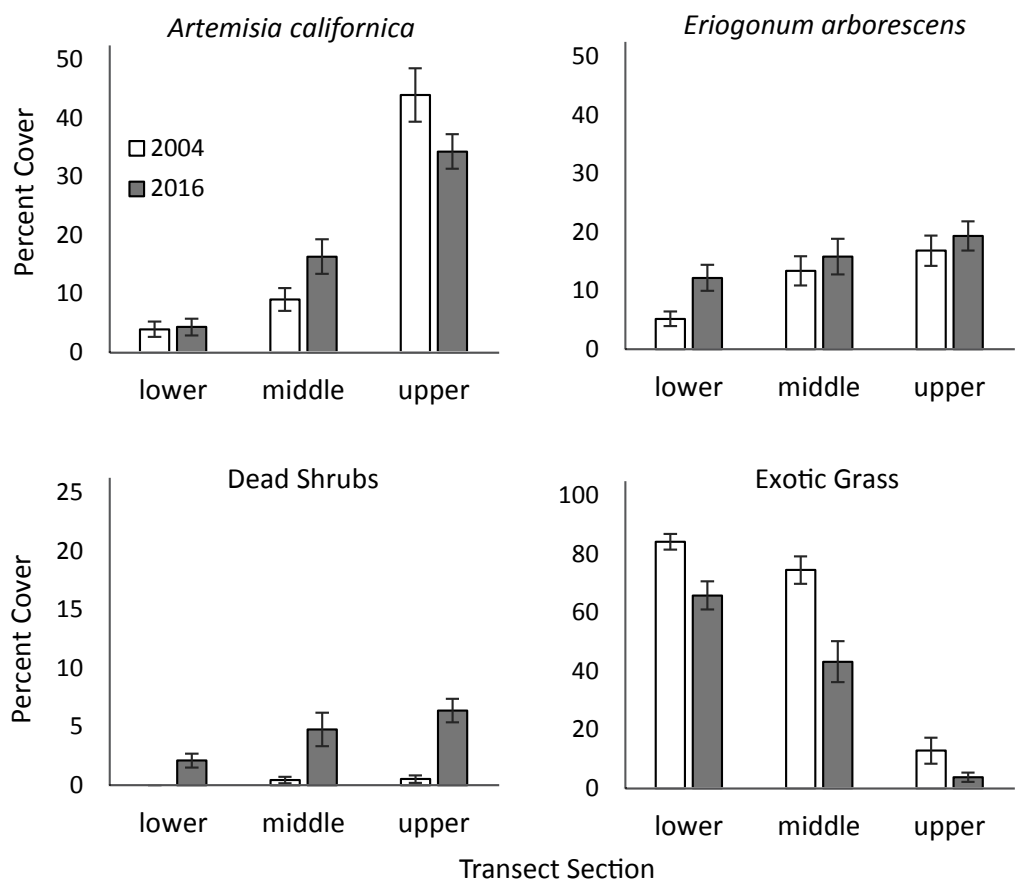

Fig. 3. Percent cover of Artemisia californica, Eriogonum arborescens, dead shrubs, and exotic grass in $5 \times 5$-m plots at the lower (exotic grass-dominated), middle (mixed shrub/grass), and upper (native shrub-dominated) sections of transects in 5 sites on Santa Cruz Island, California. Bars represent means \pm 1 SE. Statistics for GLMs are in Table 2.

this increase in cover was in the lower exotic grass-dominated sections of transects (Table 2, Fig. 3). Artemisia, on the other hand, had an increase in cover in the middle sections of transects which are a mix of grass and shrub cover overall. This species showed a decrease in shrub cover in the upper shrub-dominated portions of transects. Exotic grass cover declined in all sections of transects, although this decline was greatest in the middle sections which were transition zones between the shrub-dominated upper and the grass-dominated lower sections of transects (Table 2, Fig. 3).

\section{DisCUSSION}

Previous work in 2002-2006 showed that while seeds of both Eriogonum and Artemisia were arriving in exotic grassland areas, only Eriogonum was successfully recruiting and surviving due to the large effect of grass competition on Artemisia seedling germination and survival (Yelenik and Levine 2010). This led us to hypothesize that Eriogonum would increase in numbers of individuals and cover while Artemisia would not (Yelenik and Levine
2010). It is clear from the data that over the past 12 years various mechanisms have led to less clear patterns than hypothesized. Numbers of dead shrubs have increased for both species, suggesting high mortality due to drought conditions between 2012 and 2016, as noted by the National Oceanic and Atmospheric Administration (USDA 2017). However, slight increases in cover for both species as well as movement of shrubs farther into grassland areas than previously noted suggest that some shrub expansion is taking place for both species (Appendix 2).

Only 3 of the 12 years between sample points had above-average rainfall and all of these years were prior to a drought in California that started in 2012 (Griffin and Anchukaitis 2014). This drought was ongoing as of the final sampling date in September 2016 , with over $92 \%$ of California, including the Channel Islands, considered in "severe drought” (USDA 2017). The highest adult shrub mortality for both species took place in the upper shrub-dominated sections of transects which tend to have thinner soils than the grasslands below. These areas potentially 
have a lower water holding capacity due to thin soils, which may have affected the growth and survival of the native shrub species. Indeed, soil development and water holding capacity has been shown to affect shrub physiology, germination, growth, and survival in other systems (Harrington 1991, Hamerlynck et al. 2002, Rose et al. 2003, McCluney et al. 2012). It is also possible that the shrubs in the upper portions of transects were the first to recruit into grasslands and were therefore older than individuals lower on transects. The older shrubs may have simply reached the end of their lifespans, leading to high mortality rates.

It is probable that the decrease in exotic annual grass cover in this study, which declined by $41 \%$ in the shrub-grass transition zone and $18 \%$ in the grassland sections of transects, was caused by consecutive years of low rainfall between 2012 and 2016. Similar positive relationships between rainfall and grass biomass have been seen in other studies (Donlan et al. 2002, Levine et al. 2010). For example, cover of nonnative plants was 9 times higher in high than in low rainfall years after exotic grazers were removed in the Mojave National Preserve, California (Beever et al. 2006). Exotic annual grasses in general may be better adapted to conditions of resource abundance and thus poised to respond to high rainfall with high growth rates, and also more negatively affected by years of low rainfall (Davis et al. 2000, Drenovsky et al. 2012).

Although there was shrub mortality within the shrub-dominated portions of transects between sample dates, there was also shrub expansion into grassland areas. The average and above-average rainfall years in the beginning of the study may have led to recruitment events for native shrubs. Previous work has shown that recruitment of Eriogonum seedlings increases exponentially with an increase in rainfall and that appreciable quantities of seedlings only emerge when average rainfall conditions $(500 \mathrm{~mm} / \mathrm{year}$ ) are reached (Yelenik and Levine 2010). By these standards there were 3 chances for significant recruitment between 2004 and 2016: the 2004/05, 2007/08, and 2010/11 growing seasons.

The high variability in rainfall between 2004 and 2012 potentially further contributed to shrub expansion. Various studies have shown that interactions between climate and competition from nonnative plants exist; some show that this can drive native plant reestablishment after exotic grazer removal (Donlan et al. 2002, Chapuis et al. 2004, Holmgren et al. 2006) and native plant demographics more generally (Levine et al. 2008, 2010). Declines in annual grass cover due to consecutive dry years followed by an average or high rainfall year may have helped perennial species by allowing recruitment into annual grassland areas (Levine and Rees 2004). This would occur if annual grasses have low seed set in dry years while perennial species retain higher seed set due to internal storage mechanisms. Many perennial species have been noted to produce seed in dry years due to internal storage mechanisms (Chesson et al. 2004). Eriogonum, which shows high seed set in all years and high recruitment rates in above-average rainfall years, may be taking advantage of interannual variability in rainfall to expand its range and increase its abundance in grassland areas. More detailed demographic data across years would be needed, however, to document whether such mechanisms were driving dynamics between Eriogonum and exotic annual grasses in these study sites. It has been previously noted on Santa Cruz Island that there are pulses of native vegetation expansion into degraded/exotic-dominated areas in high rainfall years (McEachern et al. 2010). Eriogonum arborescens has also been observed to increase dramatically in numbers in other studies of shrub expansion after exotic grazer removal on Santa Cruz Island (Beltran et al. 2014, Van Vuren 2015).

In contrast, Artemisia showed the greatest increase in cover (Fig. 3) and shrub numbers (Table 1) in the middle grass-shrub transition zones of transects. This was unexpected given past results because I did not find Artemisia seedlings in shrub- or grass-dominated plots during a more intensive study period between 2004 and 2008 (Yelenik and Levine 2010). However, Artemisia seedlings were noted in more open habitats such as roadways and rocky outcrops during that time frame (S. Yelenik personal observation). It is possible that infrequent recruitment events that were difficult to see in the past study (Yelenik and Levine 2010) were still taking place and led to the modest increase in Artemisia shrubs that I observed in this study. Previous work by Van Vuren (2015), also in the Central Valley of 
Santa Cruz Island but in different sites, showed an increase in Artemisia shrubs on one of 2 transects that were established in 1980 and resampled after grazer removal in 2013. While results shown here are promising for the return of native shrub communities after exotic ungulate removal, it should be noted that native coastal sage scrub expansion may be more prevalent on the Channel Islands than in mainland Southern California sites due to high $\mathrm{N}$ deposition and thus higher exotic grass growth rates in mainland areas (Cione et al. 2002).

\section{Management Implications}

Santa Cruz Island was overstocked by exotic ungulates, leading to overgrazing and "profound" changes in vegetation island-wide, including the fragmentation of once continuous coastal sage scrub and chaparral communities (Junak et al. 1995, McEachern et al. 2010). Passive regeneration of coastal sage scrub communities dominated by Artemisia and Eriogonum are important for the continued management of this landscape. McEachern et al. (2010) noted that while rare and endangered species' populations are in some cases self-replicating and expanding, they do not seem to move outside the boundaries of intact fragments dominated by common native species. Ongoing efforts to restore rare plant populations and to facilitate further spread of rare species will be best served by predicting how fragments of common native species can reestablish across the landscape to assure suitable habitat (Noël et al. 2011, Questad et al. 2014).

Data here suggest that shrub expansion will continue, but the rates at which it will happen are most likely variable and dependent on above-average rainfall years. Climate models disagree on whether precipitation will increase or decrease in future climate scenarios (Cayan et al. 2008, Pierce et al. 2013, Allen and Luptowitz 2017), making it difficult to predict whether shrub expansion will continue in the future. A better mechanistic understanding of shrub germination and survival as they interact with precipitation patterns will inform management. Longterm data sets are needed to cross multiple drought events or to match demographic rates with interannual variability in order to evaluate the mechanisms proposed here.

\section{ACKNOWLEDGMENTS}

I thank Amanda Burgess, Clark Cowan, Steve Silvas, Anna Oliver, and Rebecca Harris who provided field help in 2004 and Meredith Stewart who provided field help in 2016. I also thank Lyndal Laughrin and Brian Guerrero of the UC Reserve System for logistic help on Santa Cruz Island. Dirk Van Vuren, Steve Hess, and one anonymous reviewer provided detailed comments that improved the manuscript. Funding was provided by the U.S. Geological Survey. Any use of trade, firm, or product names is for descriptive purposes only and does not imply endorsement by the U.S. Government.

\section{Literature Cited}

Alexander, J.M., J.M. Diez, And J.M. Levine. 2015. Novel competitors shape species' responses to climate change. Nature 525:515-518.

Allen, R.J., AND R. Luptowitz. 2017. El Niño-like teleconnection increases California precipitation in response to warming. Nature Communications 8: ncomms 16055 .

Beever, E.A., M. Huso, and D.A. Pyke. 2006. Multiscale responses of soil stability and invasive plants to removal of non-native grazers from an arid conservation reserve. Diversity and Distributions 12:258-268.

Beltran, R.S., N. Kreidler, D.H. Van Vuren, S.A. Morrison, E.S. Zavaleta, K. Newton, B.R. Tershy, and D.A. CRoLl. 2014. Passive recovery of vegetation after herbivore eradication on Santa Cruz Island, California. Restoration Ecology 22:790-797.

Bowen, L., AND D. VAN VUREN. 1997. Insular endemic plants lack defenses against herbivores. Conservation Biology 11:1249-1254.

Cayan, D.R., E.P. Maurer, M.D. Dettinger, M. Tyree, AND K. HaYhoE. 2008. Climate change scenarios for the California region. Climatic Change 87:21-42.

Chapuis, J.-L., Y. Frenot, and M. Lebouvier. 2004. Recovery of native plant communities after eradication of rabbits from the subantarctic Kerguelen Islands, and influence of climate change. Biological Conservation 117:167-179.

Chesson, P., R.L. Gebauer, S. Schwinning, N. Huntly, K. Wiegand, M.S. Ernest, A. Sher, A. NovoplanSKY, AND J.F. WeLtZIN. 2004. Resource pulses, species interactions, and diversity maintenance in arid and semi-arid environments. Oecologia 141: $236-253$.

Cione, N.K., P.E. Padgett, and E.B. Allen. 2002. Restoration of a native shrubland impacted by exotic grasses, frequent fire, and nitrogen deposition in southern California. Restoration Ecology 10:376-384.

D’Antonio, C.M., And P.M. Vitousek. 1992. Biological invasions by exotic grasses, the grass fire cycle, and global change. Annual Review of Ecology and Systematics 23:63-87.

Davis, M.A., J.P. GRIme, And K. Thompson. 2000. Fluctuating resources in plant communities: a general theory of invasibility. Journal of Ecology 88:528-534. 
Donlan, C.J., B.R. Tershy, AND D.A. Croll. 2002. Islands and introduced herbivores: conservation action as ecosystem experimentation. Journal of Applied Ecology 39:235-246.

Drenovsky, R.E., B.J. Grewell, C.M. D’Antonio, J.L. Funk, J.J. James, N. Molinari, I.M. Parker, and C.L. RiCHARDS. 2012. A functional trait perspective on plant invasion. Annals of Botany 110:141-153.

Eliason, S.A., AND E.B. Allen. 1997. Exotic grass competition in suppressing native shrubland re-establishment. Restoration Ecology 5:245-255.

Folke, C., S. Carpenter, B. Walker, M. Scheffer, T. ElmQvist, L. Gunderson, AND C.S. Holling. 2004. Regime shifts, resilience, and biodiversity in ecosystem management. Annual Review of Ecology, Evolution, and Systematics 35:557-581.

Foster, D., F. Swanson, J. Aber, I. Burke, N. Brokaw, D. Tilman, and A. Knapp. 2003. The importance of land-use legacies to ecology and conservation. BioScience 53:77-88.

Griffin, D., AND K.J. AnChuKaitis. 2014. How unusual is the 2012-2014 California drought? Geophysical Research Letters 41:9017-9023.

Guariguata, M.R., and R. Ostertag. 2001. Neotropical secondary forest succession: changes in structural and functional characteristics. Forest Ecology and Management 148:185-206.

Hamerlynck, E.P., J.R. MCAuliffe, E.V. McDonald, AND S.D. SMith. 2002. Ecological responses of two Mojave Desert shrubs to soil horizon development and soil water dynamics. Ecology 83:768-779.

HaRRington, G.N. 1991. Effects of soil moisture on shrub seedling survival in semi-arid grassland. Ecology 72:1138-1149.

Holmes, P.M., AND R. Cowling. 1997. Diversity, composition and guild structure relationships between soil-stored seed banks and mature vegetation in alien plant-invaded South African fynbos shrublands. Plant Ecology 133:107-122.

Holmgren, M., B.C. Lopez, J.R. Gutierrez, and F.A. SQueO. 2006. Herbivory and plant growth rate determine the success of El Nino Southern Oscillation-driven tree establishment in semiarid South America. Global Change Biology 12:2263-2271.

Junak, S., T. Ayers, R. Scott, D. Wilken, and D. Young. 1995. A flora of Santa Cruz Island. Santa Barbara Botanic Garden in collaboration with the California Native Plant Society, Santa Barbara, CA.

Levine, J.M., A.K. McEachern, and C. Cowan. 2008. Rainfall effects on rare annual plants. Journal of Ecology 96:795-806.

Levine, J.M., A.K. McEachern, and C. Cowan. 2010. Do competitors modulate rare plant response to precipitation change? Ecology 91:130-140.

Levine, J.M., AND M. ReEs. 2004. Effects of temporal variability on rare plant persistence in annual systems. American Naturalist 164:350-363.

McCluney, K.E., J. Belnap, S.L. Collins, A.L. González, E.M. Hagen, J.N. Holland, B.P. Kotler, F.T. Maestre, S.D. Smith, and B.O. Wolf. 2012. Shifting species interactions in terrestrial dryland ecosystems under altered water availability and climate change. Biological Reviews 87:563-582.

McEachern, A.K., K.A. Chess, AND K.G. Niessen. 2010. Field surveys of rare plants on Santa Cruz Island, California, 2003-2006: Historical records and cur- rent distributions. U.S. Geological Survey Scientific Investigations Report 2009-5264. 34 pp.

Morrison, S.A. 2007. Reducing risk and enhancing efficiency in non-native vertebrate removal efforts on islands: a 25 year multi-taxa retrospective from Santa Cruz Island, California. Pages 398-409 in G.W. Witmer, W.C. Pitt, and K.A. Fagerstone, editors, Managing vertebrate invasive species: proceedings of an international symposium. USDA/APHIS/WS, National Wildlife Research Center, Fort Collins, CO.

Noël, F., D. Prati, M. van Kleunen, A. Gygax, D. Moser, AND M. Fischer. 2011. Establishment success of 25 rare wetland species introduced into restored habitats is best predicted by ecological distance to source habitats. Biological Conservation 144:602-609.

Parkes, J.P., D.S. Ramsey, N. Macdonald, K. Walker, S. McKnight, B.S. Cohen, and S.A. Morrison. 2010. Rapid eradication of feral pigs (Sus scrofa) from Santa Cruz Island, California. Biological Conservation 143:634-641.

Pierce, D.W., T. Das, D.R. Cayan, E.P. Maurer, N.L. Miller, Y. BaO, M. Kanamitsu, K. Yoshimura, M.A. SNyder, and L.C. SloAn. 2013. Probabilistic estimates of future changes in California temperature and precipitation using statistical and dynamical downscaling. Climate Dynamics 40:839-856.

Questad, E.J., J.R. Kellner, K. Kinney, S. Cordell, G.P. Asner, J. Thaxton, J. Diep, A. Uowolo, S. Brooks, AND N. INMAN-NARAHARI. 2014. Mapping habitat suitability for at-risk plant species and its implications for restoration and reintroduction. Ecological Applications 24:385-395.

Rose, K., R. Graham, and D. Parker. 2003. Water source utilization by Pinus jeffreyi and Arctostaphylos patula on thin soils over bedrock. Oecologia 134:46-54.

Scholes, R., AND S. ARChER. 1997. Tree-grass interactions in savannas. Annual Review of Ecology and Systematics 28:517-544.

Schuyler, P. 1993. Control of feral sheep (Ovis aries) on Santa Cruz Island, California. Pages 443-452 in Advances in California Islands Research: Proceedings of the Third California Islands Symposium. Santa Barbara Museum of Natural History, Santa Barbara, CA.

Seabloom, E.W., W.S. Harpole, O.J. Reichman, and D. Tilman. 2003. Invasion, competitive dominance, and resource use by exotic and native California grassland species. Proceedings of the National Academy of Sciences 100:13384-13389.

Stohlgren, T.J., L.D. Schell, and B.V. Heuvel. 1999. How grazing and soil quality affect native and exotic plant diversity in Rocky Mountain grasslands. Ecological Applications 9:45-64.

Stylinski, C.D., And E.B. AlLEn. 1999. Lack of native species recovery following severe exotic disturbance in southern Californian shrublands. Journal of Applied Ecology 36:544-554.

Suttle, K.B., M.A. Thomsen, And M.E. Power. 2007. Species interactions reverse grassland responses to changing climate. Science 315:640-642.

[USDa] United States Department of Agriculture, National Drought Mitigation Center at the University of Nebraska-Lincoln, NOAA. 2017. U.S. Drought Monitor. Map courtesy of NDMC-UNL. [Accessed 6 January 2017]. http://droughtmonitor .unl.edu/Home/StateDroughtMonitor.aspx?CA 
Valone, T.J., M. Meyer, J.H. Brown, and R.M. Chew. 2002. Timescale of perennial grass recovery in desertified arid grasslands following livestock removal. Conservation Biology 16:995-1002.

Van Vuren, D., and B.E. Coblentz. 1987. Some ecological effects of feral sheep on Santa Cruz Island, California, USA. Biological Conservation 41:253-268.

VAN VUREN, D.H. 2015. Shrub regeneration after removal of feral sheep from Santa Cruz Island, California. California Fish and Game 100:396-403.

Wilcox, B.P., L. Turnbull, M.H. Young, C.J. Williams, S. Ravi, M.S. SEyfried, D.R. Bowling, R.L. ScotT, M.J. Germino, AND T.G. Caldwell. 2012. Invasion of shrublands by exotic grasses: ecohydrological consequences in cold versus warm deserts. Ecohydrology 5:160-173.

YeLenIK, S.G., AND C.M. D’ANTONIO. 2013. Self-reinforcing impacts of plant invasions change over time. Nature 503:517-520.

Yelenik, S.G., AND J.M. Levine. 2010. Processes limiting native shrub recovery in exotic grasslands after

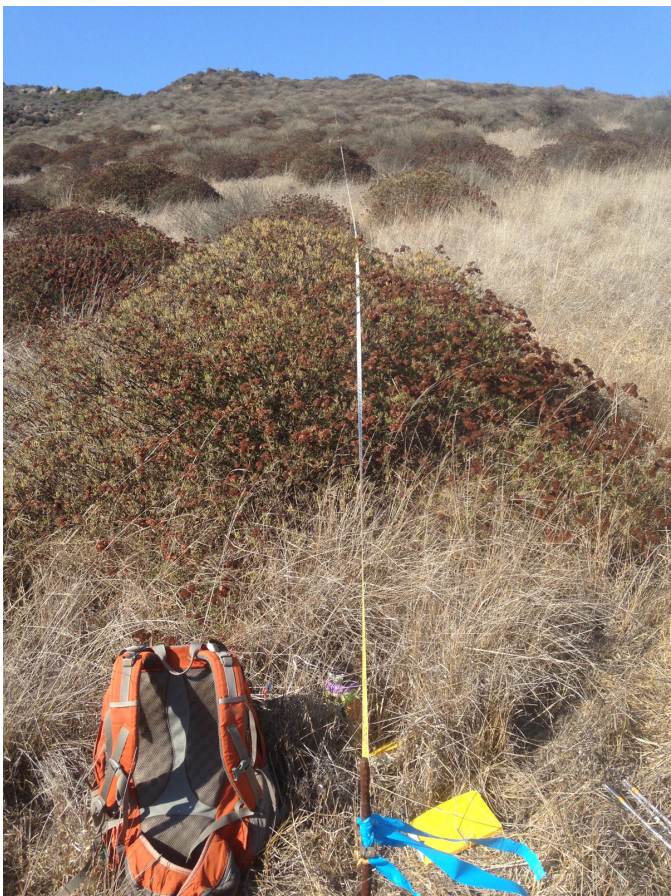

APPEndix 1. Photograph showing the transect layout, which starts in areas that were $100 \%$ grassland in 2004 , goes uphill on south-facing slopes, and ends in areas that were close to $100 \%$ native shrub in 2004 on Santa Cruz Island, California. Between grass and shrublands are transition zones with both native shrubs and exotic grasses. Photo by S. Yelenik, 2016. non-native herbivore removal. Restoration Ecology 18:418-425.

YeleniK, S.G., AND J.M. Levine. 2011. The role of plantsoil feedbacks in driving native species recovery. Ecology 92:66-74.

Young, T.P., D.A. Petersen, and J.J. Clary. 2005. The ecology of restoration: historical links, emerging issues and unexplored realms. Ecology Letters 8: 662-673.

Young, T.P., E.P. Zefferman, K.J. Vaughn, and S. Fick. 2015. Initial success of native grasses is contingent on multiple interactions among exotic grass competition, temporal priority, rainfall and site effects. AoB Plants 7:plu081.

Received 1 March 2017 Revised 13 November 2017 Accepted 28 November 2017 Published online 12 November 2018

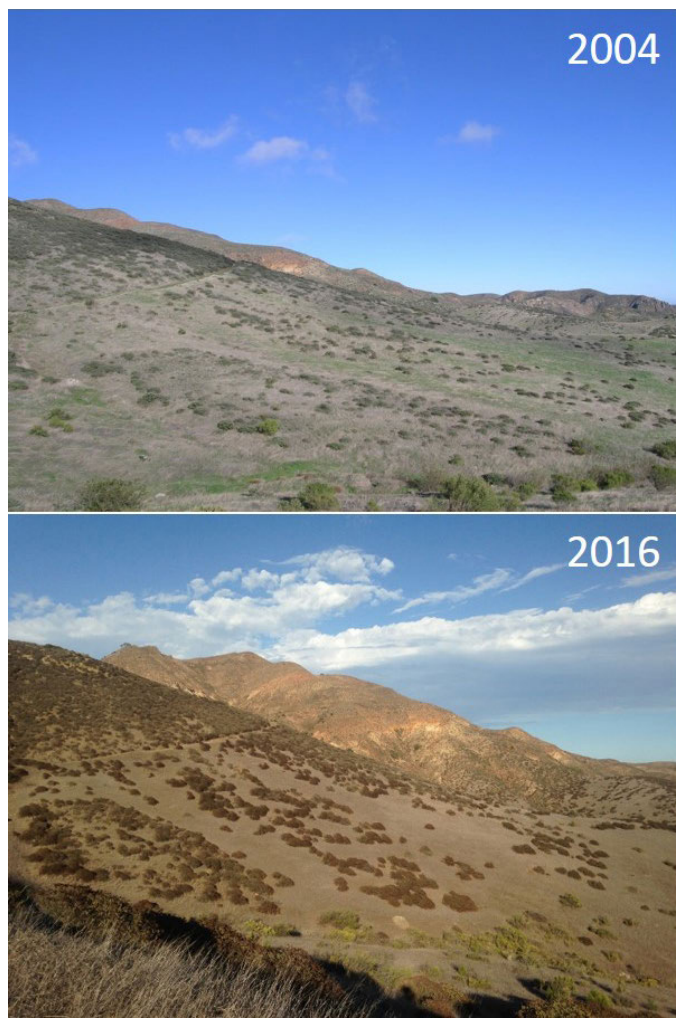

APPENDIX 2: Photographs taken from a similar spot showing south-facing slopes with Eriogonum and Artemisia shrubs and exotic grasslands in 2004 and 2016 on Santa Cruz Island, California. Though the interpretation of the photos cannot be quantitative due to the slightly different perspectives, some infilling can be seen in the upper, shrub-dominated sections of the slope. Mount Diablo can be seen in the background. Also note the pattern of shrub density decreasing in downslope areas as grasses become dominant. Photographs by S. Yelenik, 2016. 